\title{
The geochemical features and oxygen isotope composition of eclogite and clinopyroxenite xenoliths from kimberlite pipes of Siberian craton
}

TATIANA KALASHNIKOVA, SERGEY KOSTROVITSKY, LIDIYA SOLOVIEVA, KONSTANTIN SINITSYN AND ELVIRA YUDINTSEVA

The A.P. Vinogradov Institute of Geochemistry SB RAS

Presenting Author: kalashnikova@igc.irk.ru

Eclogites and clinopyroxenite mantle xenoliths from kimberlites are characterized by a similar two-mineral composition (garnet and clinopyroxene), but differ in mineralogical and petrographic features [1-4 and other]. The geochemical properties of eclogite xenoliths from kimberlite pipes suggest two main points of view for genesis: implication of subduction processes or cumulates of high-pressure melting in lithosphere mantle [2-3].

The mantle xenoliths from three Yakutian kimberlite pipes were studied (upper-Jurassic Obnajennaya pipe, Paleozoic Udachnaya and Mir pipes). Eclogites and clinopyroxenites occupy about $10-15 \%$ population among xenoliths. Garnet in the eclogites differs from that in the clinopyroxenites by a higher content of $\mathrm{CaO}$ and $\mathrm{FeO} \quad\left(\operatorname{Prp}_{55-62} \quad \mathrm{Alm}_{22-30} \mathrm{Grs}_{8-18}\right.$ in clinopyroxenites and $\operatorname{Prp}_{40-45} \mathrm{Alm}_{13-29} \mathrm{Grs}_{15-30}$ in eclogites). Clinopyroxenes are distinguished by reduced magnesia content (Mg\# 91-84), as well as low calcium content (16-18 wt.\%). The high contents of jadeite components in the clinopyroxene $\left(\mathrm{NaAl}\left[\mathrm{Si}_{2} \mathrm{O}_{6}\right]-25-32 \%\right)$ classify this group of rocks as eclogites. The high $\delta^{18} \mathrm{O}$ varies in eclogite $\mathrm{Cpx}$ (more than 6.0, mantle values $5.3 \pm 0.3[5])$, positive Eu anomaly, a relatively high content of $\mathrm{Al}_{2} \mathrm{O}_{3}$ (14-20 wt.\%) and a low $\mathrm{MgO}$ content (10-15 $\mathrm{wt} \%$ ), depletion LREE are assumed that the formation of the protolith of the xenolith group occurred as melts in the subduction zone. However, the presence of garnet clinopyroxenites with narrow variations in mineral composition and relatively low $\delta^{18} \mathrm{O}(5.5-5.8)$ suggest melting processes in the lithospheric mantle and the formation of megacrystalline pyroxene cumulates.

The research was supported by Russian Science Foundation grant №20-77-00074.

[1] Gonzaga R.G., Lowry D., Jacob D.E, LeRoex A., Schulze D. \& Menzies M.A. (2020), Journal of volcanology and geothermal research 190 (1-2 SI), 235-247.

[2] Aulbach S. \& Jacob D.E. (2016), Lithos 262, 586-605.

[3] Jacob D., Jagoutz E., Lowry D., Mattey D. Kudrjavtseva G. (1994) Geochim. et Cosmochim Acta 58, 5191-5207.

[4] Condie K.C. (1993), Chem. Geol. 104, 1-37.

[5] Mattey D., Lowry D., \& Macpherson C. (1994), Earth Planetary Science Letters 128, 231-241 